Striking out
Academics and
students take action
across Europe
p108

\title{
Transgenic planting approved despite scepticism of UK public
}

\section{Jim Giles, London}

After years of careful deliberation, the British government this week took a crucial step towards acceptance of genetically modified crops.

On 9 March, government ministers announced limited approval for commercial planting of a maize (corn) variety engineered to be resistant to a specific herbicide - the first such approval in Britain.

Although the approval lasts only until 2006, the decision indicates that prime minister Tony Blair's government is willing to support transgenic technology in the face of widespread public opposition. In Britain, opposition to agricultural biotechnology has been early and strident. Both supporters and enemies believe this week's decision will influence debates outside Britain about transgenic crops (see below).

Environment minister Margaret Beckett announced that farmers can grow the maize if they follow management guidelines used in farm-scale studies of the crop's environmental impact. These studies found that the maize could have a beneficial effect on biodiversity, provided the timing and nature of herbicide spraying are carefully controlled (see Nature 425,751;2003).

Blair's government has generally backed the technology since coming into office in 1997, but it has been cautious about allowing commercial cultivation. Opinion polls show that the public is concerned about the impact of the crops on human health and the environment, and environmental groups have campaigned against the technology.

The case for the crops was boosted by a scientific review, released last July, which found no reason to rule out carefully managed cultivation of the plants. The review was discussed at a cabinet meeting last month. Leaked minutes of the meeting state that ministers acknowledged public opposition, but thought that it "might eventually be worn down by solid, authoritative scientific argument".

Despite this week's announcement, the company marketing the maize used in the farm-scale study - Bayer CropScience, based in Monheim am Rhein, Germany — is

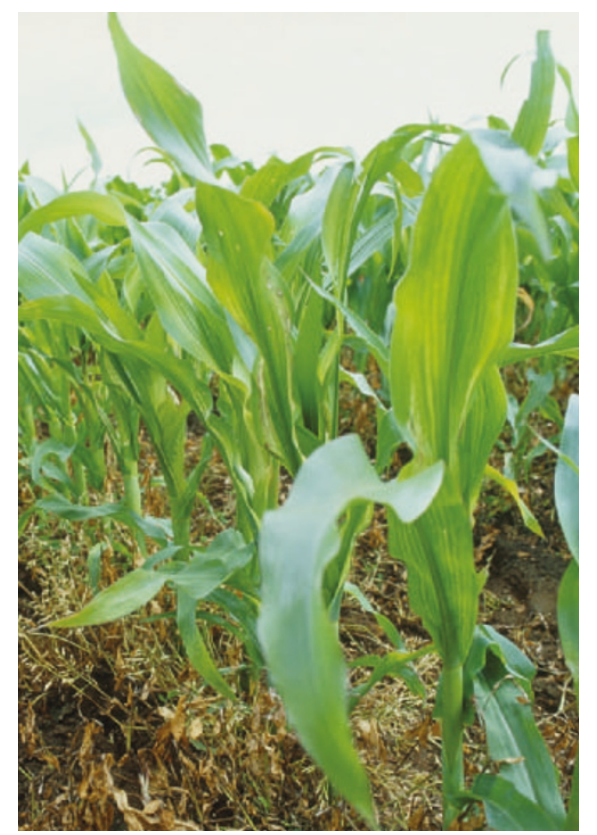

Seeds of change: British farmers could start planting genetically modified maize in 2005.

unlikely to sell many seeds in Britain in the near future. The maize has had European Union approval since 1997, but the terms of the approval will have to be modified to take

the herbicide restrictions into account before sales can start. Officials in Beckett's department say this will take several months, although they predict that the necessary rules will be in place for farmers to plant transgenic maize in spring 2005. Farmers will, however, be keeping a nervous eye on the first plantings, as environmental activists have damaged several research plots.

Farmers will also be wary of planting genetically modified varieties before the government has clarified rules governing how they should bekept separate from nearby conventional crops. In addition, European Union approval for the maize will have to be renewed if cultivation is to extend beyond 2006.

Renewing the application may not be a formality. The farm-scale trials compared transgenic maize with conventional varieties that had been treated predominantly with triazine herbicides, powerful weed-killers that are likely to be banned in Europe by 2006. When compared with fields treated with less intense herbicides, the biodiversity benefits associated with transgenic maize decrease by around a third, according to a study led Joe Perry, a statistician at Rothamsted Research, an agricultural research firm based north of London (see J. N. Perry et al. Nature doi:10.1038/nature02374; 2004).

\section{Californian county bans transgenic crops}

A rural county in northern California voted last week to become the first county in the United States to ban the planting of genetically modified crops.

Voters in Mendocino County, 130 kilometres north of San Francisco, approved the ballot initiative on 2 March by $56 \%$ to $44 \%$, despite a US $\$ 700,000$ campaign against the ban by supporters of the technology.

Similar ballot initiatives are planned in nearby Humboldt and Sonoma, and activists in half a dozen other counties in California are considering similar actions.

A state-wide ballot initiative is also being pursued in North Dakota against the planting of genetically modified wheat. The initiative is being led by a group of wheat farmers who say the crop could contaminate other strains and sabotage their export markets in countries such as Japan.

The grass-roots drive in Mendocino County was led by Els Cooperrider, a retired cancer researcher, and her husband Allen, a former zoologist, who run an organic brewery there. No transgenic plants are currently grown in the county, where grapes for wine are the main crop.

Peter Bradford, a cattleman and president of the Mendocino County Farm Bureau, says the vote was in part driven by "a fear of science and big corporations". Grape growers will probably use the ban as a marketing tool, he adds.

Agricultural corporations are considering a legal challenge to the county ban, or pursuit of state wide legislation to overturn it. Rex Dalton, San Diego 